\title{
Cardiovascular injury in anorexia nervosa
}

\author{
Afectarea cardiovasculară în anorexia nervoasă
}

\author{
Irina Calangea ${ }^{1,2}$, Ştefan Busnatu1,2, Maria Pană ${ }^{1,2}$, Cosmina Jercălău², \\ Cătălina Liliana Andrei ${ }^{1,2}$, Crina Julieta Sinescu ${ }^{1,2}$ \\ ${ }^{1}$ Universitatea de Medicină şi Farmacie „Carol Davila“, Bucureşti, România \\ ${ }^{2}$ Spitalul Clinic de Urgenţă „Bagdasar-Arseni“, Bucureşti, România
}

\begin{abstract}
Objective. Demonstrating cardiovascular injury amoung a group of female patients suffering from anorexia, compared to a similarly-aged group of women with body mass within the normal range.

Materials and methods. Clinical, biological and paraclinical parameters were determined in the two patient groups: Group A, consisting of 39 patients suffering from anorexia, and Group B, consisting of 40 patients of similar ages, but having a normal body-mass index (BMI).

Results. Compared to the normal-BMI cohort, the female patients diagnosed with anorexia are more bradycardic, have lower blood pressure, biologically were found to suffer from various degrees of anemia (hypochromic, microcytic, caused by iron deficiency), leucocytosis, thrombocytosis, hypoglicemia, slight nitrogen compounds retention, hyponatremia, hypokalemia, hypochloremia, hypomagnesemia, hypocalcemia, hypophosphatemia, low levels of triglycerides and of all cholesterol fractions, hypoproteinemia with hypoalbuminemia, mild hepatic cytolysis, increased levels of creatine kinase and cortisol. In terms of echocardiographic findings, the patients with anorexia have decreased dimensions of all cardiac chambers and of the inferior vena cava, lower cardiac output and index, diminished A-wave velocity, with an increase in E/A ratio, lower $E^{\prime}, A^{\prime}$ and $S^{\prime}$ velocities for the lateral ventricular wall, along with lower $E^{\prime}$ and $A^{\prime}$ velocities for the interventricular septum, and a decrease in both tricuspid annular and mitral annular systolic excursions.

Discussions. There is an obvious link between the magnitude of clinical, biological and paraclinical abnormalities and low BMI. Further studies are needed in order to establish the degree of reversibility of said abnormalities following the total or partial correction of the patients' nutritional deficit.

Conclusions. The patients suffering from anorexia present with multiple abnormal findings, both biological and clinical in nature, alongside a subclinical negative impact on the cardiovascular system. Early detection of these negative changes could impose the adoption of a realimentation plan, possibly accompanied by the use of specific pharmacological agents, that would bring about improvements in these patients' overall status.
\end{abstract}

Keywords: anorexia nervosa, cardiovascular impact, body-mass index

\section{REZUMAT}

Obiective. Demonstrarea afectării cardiovasculare într-un grup de paciente cu anorexie, comparativ cu un grup similar din punctul de vedere al vârstei de persoane cu greutate normală.

Material şi metodă. S-au determinat parametri clinici, biologici și paraclinici în două loturi de paciente: lotul A, format din 39 de paciente cu anorexie, și lotul B, format din 40 de paciente similare ca vârstă, dar cu greutate normală.

Rezultate. Faţă de lotul cu indice de masă corporală (IMC) normal, pacientele cu anorexie sunt mai bradicardice, hipotensive, biologic prezintă anemie de diverse grade, hipocromă microcitară, feriprivă, leucocitoză, trombocitoză, hipoglicemie, ușoară retenție azotată, hiposodemie, hipopotasemie, hipocloremie, hipomagneziemie, hipocalcemie, hipofosfatemie, scăderea trigliceridelor și a colesterolului, cu toate fracțiunile sale, hipoproteinemie cu hipoalbuminemie, citoliză hepatică ușoară, creșteri de creatinkinază și creșteri de cortizol. În ceea ce privește ecocardiografia, aceasta evidențiază la pacientele anorexice scăderea dimensiunilor tuturor cavităților cardiace și a venei cave inferioare, scăderea debitului și a indexului cardiac, scăderea velocității undei $A$, cu o creștere a raportului E/A, scăderea velocităților undelor E', A', S' la nivelul peretelui lateral și a velocităților undelor E', A' la nivelul septului interventricular, scăderea excursiei sistolice a planului inelulului tricuspidian, dar și a celui mitral. 
Discuţii. Legătura dintre magnitudinea modificărilor clinice, biologice și paraclinice și indicele de masă corporală scăzut este evidentă. Sunt necesare studii ulterioare care să stabilească gradul de reversibilitate a modificărilor după corecția totală sau parțială a deficitului nutrițional.

Concluzii. Pacientele cu anorexie prezintă multiple modificări biologice și clinice, precum și afectare subclinică a aparatului cardiovascular. Detecția timpurie a modificărilor poate impune un plan de realimentare și, eventual, medicație specifică, care să ducă la ameliorarea statusului acestor paciente.

Cuvinte cheie: anorexie nervoasă, afectare cardiovasculară, indice de masă corporală

\section{INTRODUCERE}

Deși interrelaţia dintre cardiologie și psihiatrie a fost evidențiată de mai mult timp, totuşi există încă o mare distanţă între aceste două specialități. Comunicarea dintre inimă și creier este dinamică, permanentă, bidirecțională și intens studiată. Patologiile neurologice şi psihiatrice pot determina afectare cardiovasculară, iar pacienții cu boli primitive cardiovasculare prezintă frecvent și afectare psihiatrică și/sau neurologică (1).

Prezenţa patologiei psihiatrice la pacienţii cu afecțiuni cardiologice primitive determină o calitate scăzută a vieții, o ineficiență parţială a medicaţiei, creșterea numărului de spitalizări și a zilelor de spitalizare și, implicit, costuri ridicate ale serviciilor de sănătate.

Prezenţa patologiei cardiologice la pacienții psihiatrici, condiție de multe ori ignorată, se însoțește de creșterea morbi-mortalităţii. Tulburările alimentare de orice tip, utilizarea drogurilor ilicite și a alcoolului, tulburarea depresivă, stresul, tulburările de panică și de anxietate, boala Alzheimer, tulburările bipolare, tulburările de somn, medicația psihiatrică pot determina afectarea cardiovasculară de orice tip, inclusiv patologie cu prognostic vital (2).

Complicațiile cardiovasculare ale tulburărilor alimentare sunt frecvente și se însoțesc de morbimortalitate crescută, indiferent de tipul de tulburare de alimentație. Fie că este vorba despre pacienți cu anorexie, cu bulimie, cu supraalimentație compulsivă sau cu alimentație în salturi (binge eating), complicațiile cardiovasculare sunt des întâlnite, ele fiind însă diferite în funcție de tipul afecțiunii de bază. În întreaga lume, se estimează că peste 70 de milioane de persoane suferă de tulburări alimentare (3). Dintre toate tipurile acestor afecțiuni, anorexia nervoasă este cea mai frecventă și cea mai studiată. În anul 2018, datele statistice globale arată că anorexia nervoasă este a treia boală cronică a adolescentelor, având cel mai rezervat prognostic şi cea mai mare mortalitate dintre toate afecțiunile psihiatrice. Un număr mai mare de cazuri este întâlnit la eleve (1-2\%), studente $(3,5 \%)$ şi balerine $(7 \%)(4,5)$.
Recente studii de epidemiologie a anorexiei arată o incidență de 8-13/100.000 pe an și o prevalenţă de $0,3 \%$. Se demonstrează afectarea femeilor mai mult decât a bărbaților, în special a tinerelor adolescente, cele între 15 și 19 ani (mai mult de $40 \%$ din totalul celor care suferă de această boală) (6).

În ceea ce privește rata de mortalitate, anorexia nervoasă are cel mai mare procent dintre toate bolile psihiatrice şi depășește, de asemenea, alte boli grave ale adolescentului, cum ar fi astmul, diabetul zaharat de tip 1 (anorexia nervoasă - rată de mortalitate $=11,5 \%)(7)$.

De fapt, mortalitatea în cazul anorexiei nervoase este de 12 ori mai mare decât a populației în general. De asemena, rata de suicid este extrem de ridicată, de 56 de ori mai mare decât în populația sănătoasă (8).

Referitor la costurile privind tulburările de alimentație, în Anglia au fost estimate la 80-100 de milioane de dolari, faţă de suma globală de costuri, de aproximativ 1,26 miliarde de dolari anual. De asemenea, conform studiilor recente, realizate de FREED (Foundation For Research And Education In Eating Disorders), costurile pentru cercetarea anorexiei nervoase per pacient sunt de 0,93 \$, în comparație cu cele pentru autism (44 \$), schizofrenie (81 \$), demența Alzheimer (88\$) $(9,10)$.

Este astfel justificată o cercetare amănunţită a afectării cardiovasculare la pacientele anorexice, în vederea descoperirii precoce a modificărilor, mai ales a celor subclinice şi, astfel, pentru a putea stabili un plan de tratament adecvat.

\section{OBIECTIVE}

Studiul şi-a propus analizarea unui grup de paciente cu anorexie nervoasă, aflate în diferite stadii de boală, clinic, biologic şi paraclinic, şi compararea parametrilor determinaţi cu cei dintr-un grup de paciente normoponderale cu vârstă comparabilă. S-au realizat comparaţii între diverşi parametri, în încercarea de a stabili legătura dintre modificările obiectivate şi durata anorexiei sau indicele de masă corporală. 


\section{MATERIAL ŞI METODĂ}

S-a realizat un studiu observațional prospectiv. S-au înrolat în proporții aproximativ egale paciente cu anorexie nervoasă - grup A (IMC $<17,5 \mathrm{~kg} / \mathrm{m}^{2}$ sc, diagnosticate după criteriile DSM-V: The Diagnostic and Statistical Manual of Mental Disorders), provenite din clinici de psihiatrie, și persoane $\mathrm{cu}$ greutate normală - grup B (IMC 18-24,99 kg/m² sc).

Pentru punerea diagnosticului de anorexie nervoasă s-a aplicat SCID I (interviu clinic structurat) pentru determinarea tulburărilor psihice de pe axa I, dar și SCID II pentru diagnosticarea tulburărilor de personalitate de pe axa II. De asemenea, s-a aplicat inventarul pentru tulburările de alimentație (EDI), instrument diagnostic folosit pentru a evalua prezența unei tulburări de alimentație. Subiecții din cele două loturi au fost echivalenți din punctul de vedere al distribuției pe grupe de vârstă și pe sexe. Toți subiecţii au fost evaluați multidisciplinar la înrolare. Totodată, li s-a aplicat și un chestionar de evaluare a calității vieții. S-au efectuat: examen psihiatric complet, inclusiv chestionar de calitate a vieții, examen cardiologic complet anamneză, cu colectare de date generale, examen fizic complet, profil biologic complet, examinare ECG de repaus şi Holter ECG, monitorizare 24 de ore a tensiunii arteriale, ecocardiografie completă.

Analiza datelor a îmbinat metode, mijloace şi tehnici din domeniul statisticii cu cercetare ştiinţifică medicală (o echipă de cardiologi și psihiatri) pentru a dezvolta un model integrativ de abordare a pacienților cu dezechilibre nutriționale, cu îmbunătățirea prognosticului acestora.

Criteriile de includere în acest studiu au fost: pacienți majori, cu anorexie nervoasă, indiferent de severitatea anorexiei și de durata sa, indiferent de prezența sau absența tratamentului psihiatric, $\mathrm{cu}$ acceptul pacienților de a fi examinați și monitorizați pe termen lung.

Criteriile de excludere din acest studiu au fost: anorexie: pacienți cu date inițiale incomplete, cu refuzul semnării consimțământului informat, cu absența posibilităţii contactării ulterioare, cu excluderea principalelor cauze medicale ce pot determina scădere în greutate sau malabsorbție: neoplazii, infecții cronice (HIV, TBC), diabet zaharat dezechilibrat, hipertiroidism, boală celiacă, boli inflamatorii intestinale; normoponderali: pacienți cu date inițiale incomplete, cu refuzul semnării consimțământului informat, cu absența posibilității contactării ulterioare. S-au urmărit variabile demografice, clinice, paraclinice și de calitate a vieții.

Studiul a fost condus în concordanţă cu principiile etice din Declaraţia Drepturilor Omului de la
Helsinki, punând pe primul plan starea de bine şi siguranţa pacienţilor, supravegherea şi deciziile medicale fiind întotdeauna în favoarea pacienţilor analizaţi.

Baza de date a fost creată în Microsoft Office Excel 2007. A fost efectuată iniţial o analiză univariată a datelor selectate. Variabilele au fost de tip: întreg, real sau boolean. A fost studiată fiecare variabilă urmărită. În analiza supravieţuirii, ca urmare a cenzurării datelor, anumite mărimi statistice pot să nu fi avut proprietăţile statistice dorite. De aceea, a fost necesară utilizarea altor mărimi pentru caracterizarea fenomenului studiat. O metodă importantă a fost aceea de estimare a funcţiei de repartiţie a mărimii studiate. Datele au fost prelucrate (analiză multivariată) utilizând modelul lui Cox, regresia hazardului proporţional, pentru a se obţine corelațiile statistice între variabilele luate în studiu.

\section{REZULTATE}

Analiza parametrilor epidemiologici a arătat că pacientele cu anorexie tind să fie mai tinere, cu o vârstă medie în grupul analizat de 21,69 ani, față de vârsta medie din grupul persoanelor cu greutate normală, de 24,78 ani. Din punctul de vedere al mediului de proveniență, sunt similare cu lotul de normalitate $(79,48 \%$ proveniență din mediul urban la anorexice și $87,5 \%$ în lotul de normali) și au un nivel educațional mai ridicat faţă de lotul de normalitate $(10,25 \%$ absolvire liceu, $69,23 \%$ absolvire facultate, $20,51 \%$ studii postuniversitare în lotul de anorexie, 22,5\% absolvire liceu, $60 \%$ absolvire facultate, $17,5 \%$ studii postuniversitare în lotul cu IMC normal). În grupul A, 18 paciente $(46,15 \%)$ au fost încadrate după IMC în forma uşoară de anorexie, 18 paciente $(46,15 \%)$ în forma medie şi 3 paciente $(7,69 \%)$ în forma severă (Fig. 1).

Calitatea vieții în grupul pacientelor anorexice a fost net mai scăzută față de grupul cu IMC normal, direct proporțional cu indicele de masă corporală scăzut, corelație cu înaltă semnificație statistică $(p=0,000)$. Astfel: $56,41 \%$ dintre pacientele cu anorexie au declarat că au o calitate scăzută a vieții, față de 7,5\% dintre pacientele cu greutate normală. Statutul financiar al pacientelor anorexice a fost ușor mai ridicat față de cel al pacientelor cu greutate normală, 53,84\% având un statut mediu, iar $46,15 \%$ un statut ridicat în grupul de anorexie, faţă de $47,5 \%$ statut mediu și $42,5 \%$ statut ridicat în grupul de comparație. Indicele de masă corporală din grupul de anorexie a fost de 16,79 $\mathrm{kg} / \mathrm{m}^{2} \mathrm{sc}$, față de $22,33 \mathrm{~kg} / \mathrm{m}^{2}$ sc în grupul cu IMC 


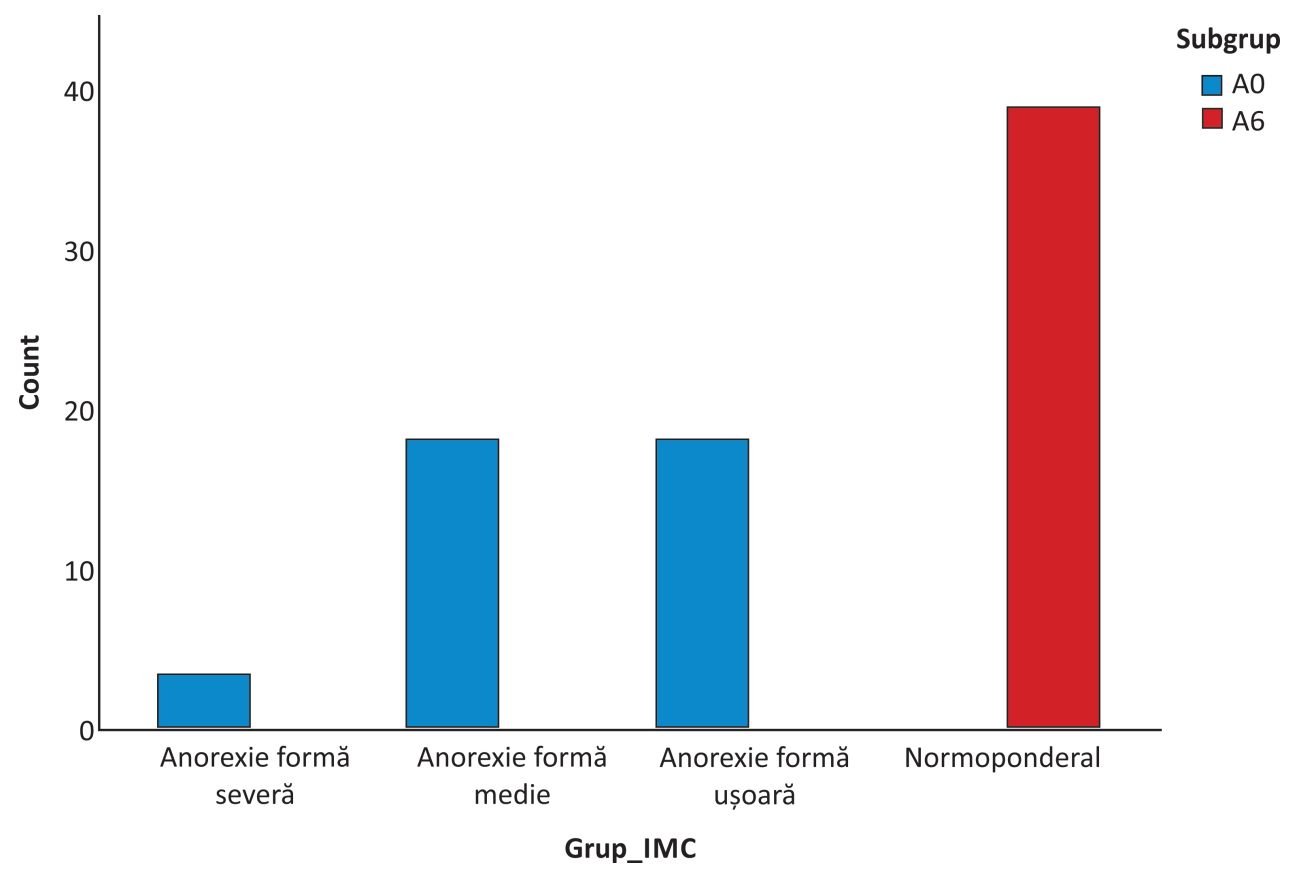

FIGURA 1. Clasificarea anorexiei în funcție de IMC

normal. Valoarea medie a anilor de anorexie a fost de 5,23 ani. Cu cât durata anorexiei a fost mai lungă, cu atât indicele de masă corporală a fost mai scăzut $(p=0,000)$. În grupul A, IMC-ul se corelează semnificativ statistic negativ cu anii de anorexie şi pozitiv cu calitatea vieţii. Cu cât pacientele au mai mulţi ani de anorexie, cu atât IMC-ul este mai mic şi calitatea vieţii mai scăzută (Tabel 1).

$48,71 \%$ dintre pacienții cu anorexie erau cunoscuți cu antecedente personale patologice de tulburări de alimentație, acestea lipsind în grupul de control. De asemenea, antecedentele heredo-

TABEL 1. Corelația IMC cu parametri demografici

\begin{tabular}{|c|c|c|c|c|c|c|}
\hline & $\begin{array}{c}\mathrm{IMC} \\
\left(\mathrm{kg} / \mathrm{m}^{2} \mathrm{sc}\right)\end{array}$ & $\begin{array}{c}\text { Mediu de } \\
\text { provenienţă }\end{array}$ & $\begin{array}{c}\text { Nivel } \\
\text { educaţional }\end{array}$ & $\begin{array}{c}\text { Statut } \\
\text { financiar }\end{array}$ & $\begin{array}{c}\text { Calitatea } \\
\text { vieţii }\end{array}$ & $\begin{array}{c}\text { Ani de } \\
\text { anorexie }\end{array}$ \\
\hline \multirow[t]{3}{*}{$\mathrm{IMC}(\mathrm{kg} / \mathrm{m} 2 \mathrm{sc})$} & $\begin{array}{l}\text { Pearson } \\
\text { Correlation }\end{array}$ & 1 & -.054 & -.053 & -.051 & $.843^{* *}$ \\
\hline & Sig. (2-tailed) & & .742 & .747 & .759 & .000 \\
\hline & $\mathrm{N}$ & 39 & 39 & 39 & 39 & 39 \\
\hline \multirow[t]{3}{*}{$\begin{array}{l}\text { Mediu de } \\
\text { provenienţă }\end{array}$} & $\begin{array}{l}\text { Pearson } \\
\text { Correlation }\end{array}$ & -.054 & 1 & -.096 & -.088 & .066 \\
\hline & Sig. (2-tailed) & .742 & & .563 & .593 & .691 \\
\hline & $\mathrm{N}$ & 39 & 39 & 39 & 39 & 39 \\
\hline \multirow[t]{3}{*}{ Nivel educaţional } & $\begin{array}{l}\text { Pearson } \\
\text { Correlation }\end{array}$ & -.053 & -.096 & 1 & $.486^{* *}$ & -.071 \\
\hline & Sig. (2-tailed) & .747 & .563 & & .002 & .670 \\
\hline & $\mathrm{N}$ & 39 & 39 & 39 & 39 & 39 \\
\hline \multirow[t]{3}{*}{ Statut financiar } & $\begin{array}{l}\text { Pearson } \\
\text { Correlation }\end{array}$ & -.051 & -.088 & $.486^{* *}$ & 1 & .016 \\
\hline & Sig. (2-tailed) & .759 & .593 & .002 & & .923 \\
\hline & $N$ & 39 & 39 & 39 & 39 & 39 \\
\hline \multirow[t]{3}{*}{ Calitatea vieţii } & $\begin{array}{l}\text { Pearson } \\
\text { Correlation }\end{array}$ & $.843^{* *}$ & .066 & -.071 & .016 & 1 \\
\hline & Sig. (2-tailed) & .000 & .691 & .670 & .923 & \\
\hline & $\mathrm{N}$ & 39 & 39 & 39 & 39 & 39 \\
\hline \multirow[t]{3}{*}{ Ani de anorexie } & $\begin{array}{l}\text { Pearson } \\
\text { Correlation }\end{array}$ & $-.664^{* *}$ & .212 & .004 & -.008 & $-.761^{* *}$ \\
\hline & Sig. (2-tailed) & .000 & .196 & .982 & .960 & .000 \\
\hline & $\mathrm{N}$ & 39 & 39 & 39 & 39 & 39 \\
\hline
\end{tabular}

**. Corelaţia este semnificativă la $p=0,01$ 
colaterale au fost semnificative la acești pacienți, prezente într-un procent de 53,84\%, lipsind în grupul de control.

Din punctul de vedere al parametrilor clinici, pacientii anorexici sunt mai bradicardici, cu o medie a alurii ventriculare de repaus de $61,56 \mathrm{~b} / \mathrm{min}$, faţă de $72,4 \mathrm{~b} / \mathrm{min}$ în grupul de control. Valorile tensiunii arteriale sistolice sunt mai scăzute în cazul pacientelor anorexice, cu o medie de $91,79 \mathrm{~mm}$ $\mathrm{Hg}$, față de 115,4 mm Hg în grupul cu IMC normal. Pacientele cu anorexie prezintă frecvent hipotensiune arterială ortostatică, având valori medii ale tensiunii arteriale sistolice de $83,46 \mathrm{~mm} \mathrm{Hg}$, faţă de 113,13 mm Hg în lotul de comparaţie. Atât valorile scăzute ale alurii ventriculare, cât și valorile scăzute ale tensiunii arteriale sistolice în clino și în ortostatism se corelează înalt semnificativ statistic cu indicele de masă corporală scăzut. Intervalul QTc a avut o valoare medie de $400 \mathrm{msec}$ în grupul de anorexie și $340 \mathrm{msec}$ în grupul de comparație.

Din punct de vedere biologic, pacientele anorexice prezintă un grad de anemie (eritrocite - valoare medie $4,34 \times 10^{5 / \mathrm{mm}^{3}}$ față de $4,91 \times 10^{5 /} \mathrm{mm}^{3}$ în grupul cu IMC normal, hemoglobină - valoare medie $12,93 \mathrm{~g} / \mathrm{dl}$, față de $13,09 \mathrm{~g} / \mathrm{dl}$ în grupul cu IMC normal, hematocrit 39,26\% față de 45,2\% în grupul cu IMC normal), hipocromă, microcitară (MCV - valoare medie 75,15 fl, față de 83,08 fl în grupul de normal, $\mathrm{MCH}$ - valoare medie 26,31 pg față de 29,08 pg în grupul de normali), feriprivă (sideremie - valoare medie 49,95 mcg/dl, față de $107 \mathrm{mcg} / \mathrm{dl}$ în grupul cu IMC normal). Acești parametri se corelează direct proporțional înalt semnificativ statistic cu indicele de masă corporală scăzut, cu un $\mathrm{p}=0,000$. Pacientele cu anorexie prezintă mai frecvent leucocitoză (globule albe valoare medie $7,36 \times 10^{3} / \mathrm{mm}^{3}$, față de $7,03 \times 10^{3} /$ $\mathrm{mm}^{3}$ în grupul cu IMC normal) și trombocitoză (trombocite - valoare medie de $327,59 \times 10^{3} / \mathrm{mm}^{3}$ față de $321,95 \times 10^{3} / \mathrm{mm}^{3}$ în grupul cu IMC normal). Acești doi parametri nu sunt semnificativ diferiţi statistic față de grupul cu IMC normal și nici nu prezintă corelație cu indicele de masă corporală.

Pacientele anorexice au prezentat valori mult scăzute ale glicemiei $(65,79 \mathrm{mg} / \mathrm{dl}$ media, faţă de $82,35 \mathrm{mg} / \mathrm{dl}$ în grupul de control), retenție azotată uşoară, explicată cel mai probabil prin deshidratare (uree - valoare medie 51,77 mg/dl, faţă de 30,05 $\mathrm{mg} / \mathrm{dl}$ în grupul de control, creatinină $1,16 \mathrm{mg} / \mathrm{dl}$ valoare medie faţă de $0,76 \mathrm{mg} / \mathrm{dl}$ în grupul de control), valori scăzute ale acidului uric seric (medii de 2,89 mg/dl față de 3,86 mg/dl în grupul de con- trol) și diselectrolitemii importante: hiposodemie, hipopotasemie, hipocloremie, hipomagneziemie, hipocalcemie și hipofosfatemie (sodiu valoare medie de $134,15 \mathrm{mmol} / \mathrm{l}$, față de $138,35 \mathrm{mmol} / 1$ în grupul de control, potasiu valoare medie de 3,55 mmol/1, față de 4,23 mmol/l în grupul de control, clor valoare medie de 99,05 mmol/1, față de 100,63 $\mathrm{mmol} / \mathrm{l}$ în grupul de control, magneziu valoare medie de $1,73 \mathrm{mg} / \mathrm{dl}$, față de $2 \mathrm{mg} / \mathrm{dl}$ în grupul de control, calciu total valoare medie de $8,59 \mathrm{mg} / \mathrm{dl}$, față de $9,18 \mathrm{mg} / \mathrm{dl}$ în grupul de control, calciu ionic valoare medie de $4,25 \mathrm{mg} / \mathrm{dl}$, față de $4,70 \mathrm{mg} / \mathrm{dl}$ în grupul de control, fosfor seric valoare medie de $2,87 \mathrm{mg} / \mathrm{dl}$, față de $3,45 \mathrm{mg} / \mathrm{dl}$ în grupul de control).

Profilul lipidic al pacientelor cu anorexie a fost caracterizat de hipocolesterolemie, cu scăderea tuturor fracțiunilor colesterolului și hipotrigliceridemie (colesterol total - valoare medie $88,87 \mathrm{mg} / \mathrm{dl}$, față de 151,9 mg/dl în grupul de control, LDL colesterol - valoare medie de 56,44 mg/dl, față de 92,73 mg/dl în grupul de control, HDL colesterol valoare medie de $24,97 \mathrm{mg} / \mathrm{dl}$, față de $87,5 \mathrm{mg} / \mathrm{dl}$ în grupul de normali, trigliceride - valoare medie de $56,18 \mathrm{mg} / \mathrm{dl}$, față de $87,5 \mathrm{mg} / \mathrm{dl}$ în grupul de control). Pacientele din grupul A au prezentat hipoproteinemie cu hipoalbuminemie (proteine totale - valoare medie de 5,93 g/dl, față de 7,54 g/dl în grupul de normal, albumină - valoare medie de 3,06 g/dl, faţă de 4,26 g/dl în grupul de control), citoliză hepatică ușoară (ALT valoare medie de $52,85 \mathrm{mg} / \mathrm{dl}$, faţă de 37,65 mg/dl în grupul de control, AST valoare medie de $28,85 \mathrm{mg} / \mathrm{dl}$, față de $24,93 \mathrm{mg} / \mathrm{dl}$ în grupul de control), creșteri de creatinkinază, foarte probabil pe baza fracțiunii musculare (CK - valoare medie de 95,44 U/1, față de 81,53 U/l în grupul de control), și creșteri de cortizol seric (valoare medie de 436,13 nmol/1, față de 274 nmol/l în grupul de control).

Analiza parametrilor ecocardiografici a evidențiat în cazul pacientelor cu anorexie scăderea dimensiunilor tuturor cavităților cardiace (aria atriului stâng - valoare medie de $10,55 \mathrm{~cm}^{2}$ față de $14,63 \mathrm{~cm}^{2}$ în grupul de control, diametrul telediastolic al ventriculului stâng - valoare medie de 36 mm, față de 41,95 mm în grupul de control, diametru telesistolic al ventriculului stâng - valoare medie $22,28 \mathrm{~mm}$, față de $25,7 \mathrm{~mm}$ în grupul de control, sept interventricular - valoare medie 6,33 mm, față de 7,93 mm în grupul de control, perete posterior ventricul stâng - valoare medie $6,49 \mathrm{~mm}$, faţă de $7,88 \mathrm{~mm}$ în grupul de control, volum telesistolic ventricul stâng - valoare medie $18,62 \mathrm{ml}$, față de 32,25 ml în grupul de control, volum tele- 
diastolic al ventriculului stâng - valoare medie de 46,92 ml, față de 71,4 ml în grupul de control, masa ventriculului stâng - valoare medie de $68,85 \mathrm{~g}$, față de 113,10 g în grupul de control, arie atriu drept - valoare medie $11,05 \mathrm{~cm}^{2}$, față de $12,36 \mathrm{~cm}^{2}$, ventricul drept - valoare medie de $24,59 \mathrm{~mm}$, față de 29,23 mm în grupul de control, inel aortic - valoare medie $17,51 \mathrm{~mm}$, față de $18,45 \mathrm{~mm}$ în grupul de control, vena cavă inferioară - valoare medie de 13,49 mm, față de 16,55 mm în grupul de control). Fracția de ejecție a ventriculului stâng a avut valori normale, cu o medie de 59,10\%, faţă de $61,23 \%$ în grupul de normal. Excursia sistolică a planului ine- lului mitral are valori medii de $10,95 \mathrm{~mm}$ în grupul A, faţă de 12,83 mm în grupul de control, fiind scăzută și la nivelul inelului tricuspidian, cu o medie de $18,21 \mathrm{~mm}$, față de $21,38 \mathrm{~mm}$ în grupul de control. Debitul cardiac și indexul cardiac sunt scăzute la pacientele cu anorexie față de grupul cu IMC normal (debit cardiac - valoare medie 4,83 1/min, față de 5,42 1/min în grupul de control, index cardiac - valoare medie de $2,88 \mathrm{1} / \mathrm{min} / \mathrm{m}^{2}$ sc, față de 3,271/min/m² sc în grupul de control) (Fig. 2, Fig. 3).

În grupul $\mathrm{A}$, prolapsul de valvă mitrală a fost întâlnit la 45\% dintre paciente, cu regurgitare mitrală ușoară-medie, iar prolapsul de valvă tricuspidă

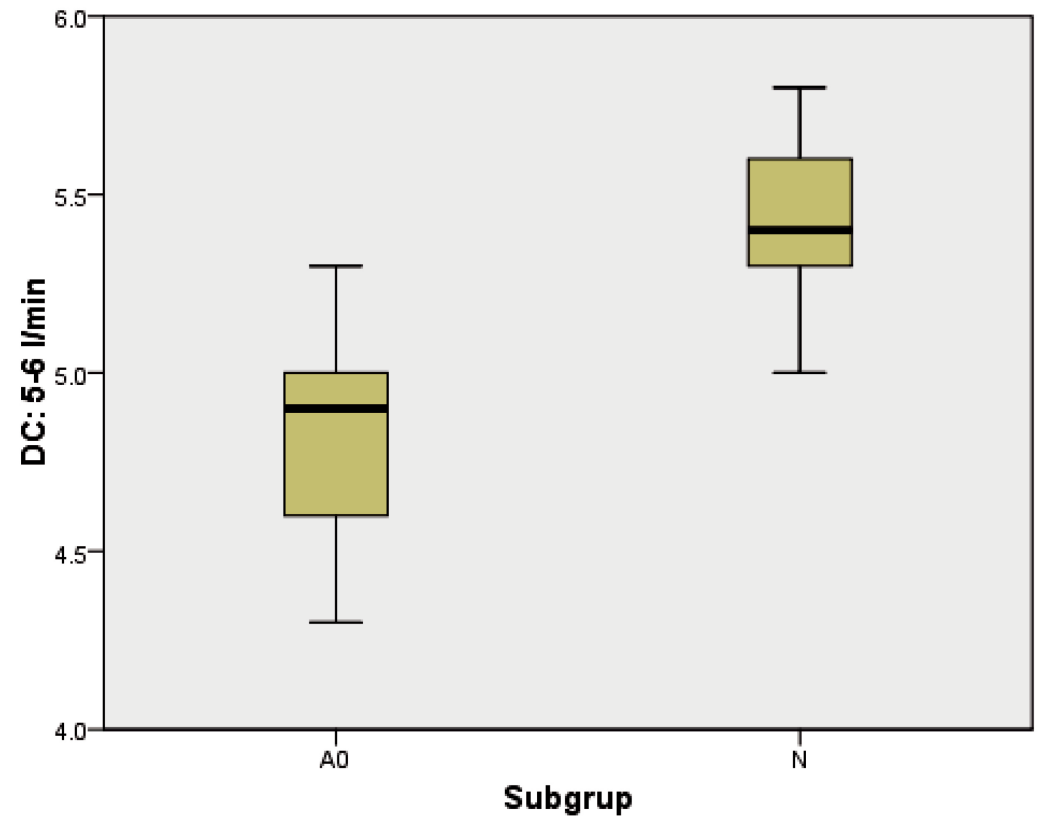

FIGURA 2. Compararea debitului cardiac (DC) între cele două grupuri

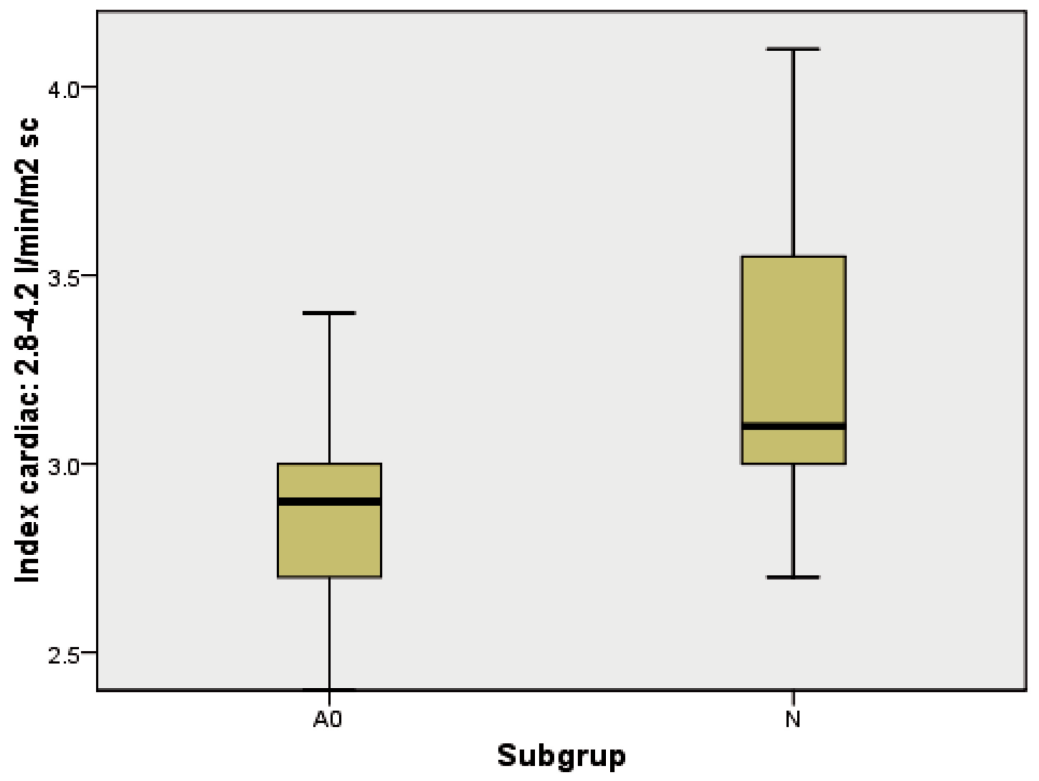

FIGURA 3. Compararea indexului cardiac între cele două grupuri 
la $14 \%$ dintre paciente, cu regurgitare tricuspidiană maximum moderată, însă fără hipertensiune pulmonară. Analiza fluxului diastolic transmitral a arătat că pacienții cu anorexie au prezentat o valoare medie a velocității maxime a undei $\mathrm{E}$ de $80,92 \mathrm{~cm} / \mathrm{sec}$, faţă de cei din grupul normal, care au avut o valoare medie de $81,05 \mathrm{~cm} / \mathrm{sec}$, pacienții cu anorexie au avut o valoare medie a velocității undei A de 45,05 cm/sec, valoare mult redusă față de cea a pacienților din grupul normal, respectiv $68,75 \mathrm{~cm} / \mathrm{sec}$, pacienții cu anorexie au prezentat o valoare medie a raportului E/A de 1,81, valoare mai crescută față de cea a pacienților din grupul normal, respectiv 1,18. Analiza Tissue Doppler a arătat faptul că pacienții cu anorexie au avut o valoare medie a velocității undei S' la nivelul septului interventrucular de $6,73 \mathrm{~cm} / \mathrm{sec}$, față de pacienții din grupul normal, care au avut o valoare medie a velocității undei S' la acest nivel de $7,52 \mathrm{~cm} / \mathrm{sec}$, pacienții cu anorexie au avut o valoare medie a velocităţii undei E' la nivelul septului interventricular de $6,31 \mathrm{~cm} / \mathrm{sec}$, iar cei din grupul cu IMC normal au avut o valoare medie de $8,77 \mathrm{~cm} / \mathrm{sec}$. Pacienții cu anorexie au avut o valoare medie a velocității undei A' la SIV de $6,98 \mathrm{~cm} / \mathrm{sec}$, față de pacienții din grupul cu IMC normal, care au prezentat o valoare medie de $7,67 \mathrm{~cm} / \mathrm{sec}$. La nivelul peretelui lateral, pacienții cu anorexie au avut o valoare medie a undei $E^{\prime}$ de $6,31 \mathrm{~cm} / \mathrm{sec}$, iar pacienții din grupul cu IMC normal au avut o valoare medie de $8,77 \mathrm{~cm} / \mathrm{sec}$, o valoare medie a undei A' de $6,98 \mathrm{~cm} / \mathrm{sec}$, față de 7,67 cm/sec în grupul cu IMC normal și o valoare medie a undei S' de $6,73 \mathrm{~cm} / \mathrm{sec}$, față de $7,52 \mathrm{~cm} / \mathrm{sec}$ în grupul cu IMC normal.

\section{DISCUŢII}

Pacienții cu anorexie sunt de obicei femei tinere, ce provin majoritar din mediul urban, având un statut financiar și un nivel educațional superior. Față de cei cu greutate normală, acestea au AHC și APP de tulburări de alimentație, au o calitate a vieții scăzută, direct proporțional cu IMC scăzut și cu durata anilor de anorexie, sunt bradicardice şi hipotensive. Grupul studiat este format doar din femei, însă există şi cazuri descrise la bărbaţi, dar mult mai rar. În studiile publicate în literatură, pacientele au în general vârste mai mici, de obicei între 15 şi 19 ani (11). Datele din literatură arată majoritatea pacientelor cu anorexie ca fiind la liceu, dată fiind de fapt vârsta mult mai mică a pacientelor studiate (12). Din punctul de vedere al mediului de provenienţă, rezultatele sunt similare cu cele din studiile din literatură. Pentru statutul financiar nu am găsit date de comparaţie în literatură (13). Din punctul de vedere al calităţii vieţii, datele sunt similare cu cele publicate până în prezent (14).

În ceea ce privește hemoleucograma, aceasta decelează faptul că pacienții suferind de anorexie sunt anemici, cu globule roșii cu indici scăzuți, uneori cu valori crescute ale trombocitelor și leucocitelor. Aceste valori se corelează cu datele din literatură, anemia fiind una dintre cele mai frecvente consecințe ale anorexiei. Alimentația deficitară și inaniția conduc la pierdere marcate de fier în organism, fapt observat şi în grupul de studiu. Datele din literatură arată că pacienţii cu anorexie pot prezenta în egală măsură leucocitoză, leucopenie sau pot avea formulă leucocitară normală. De asemenea, pot prezenta trombocitoză, trombocitopenie sau număr normal de plachete, fără corelaţie cu gradul anorexiei (15).

Ionograma serică arată diselectrolitemii precum: hiponatremie, hipopotasemie, hipocloremie, hipofosfatemie, hipocalcemie, hipomagneziemie. Restricția alimentară în anorexie prezintă ca o consecință secundară pierderea de minerale esențiale bunei funcționări celulare, aşa cum arată şi datele publicate până în prezent (16).

Totodată, pacienții cu anorexie au alterări ale metabolismului glucidic (frecvent hipoglicemie), ale metabolismului proteic (valori scăzute ale proteinelor plasmatice), dar prezintă și modificări ale metabolismului lipidic (valori scăzute ale colesterolului, LDL, HDL, trigliceridelor). Funcția hepatică prezintă modificări precum creșteri ale enzimelor hepatice (AST, ALT). De asemenea, funcția renală este afectată, existând creșteri ale valorilor creatininei și ureei, foarte probabil pe seama deshidratării. Toate aceste date sunt concordante cu cele regăsite în literatură $(17,18)$. Aceste modificări se corelează direct cu gradul anorexiei, existând date care arată şi reversibilitatea lor o dată cu îmbunătăţirea statusului nutriţional.

În ceea ce privește ecocardiografia, aceasta evidențiază la pacienții anorexici scăderea tuturor dimensiunilor cavităților cardiace, atât în valoare absolută, cât și indexate. Există o scădere a debitului și a indexului cardiac. Datele din literatură arată modificări similare $(19,20)$. Deși fracția de ejecție a ventriculului este păstrată multă vreme, există totuși notate valori ușor mai reduse față de lotul de control. La pacientele cu forme avansate de anorexie, pot exista disfuncţii sistolice importante de ventricul stâng $(20,21)$.

De asemenea, la acești pacienți, s-a observat o scădere a velocității undei A, cu o creștere a rapor- 
tului E/A. În plus, velocităţile undelor E', A', S' la nivelul peretelui lateral au fost reduse, la fel și valorile velocităților undelor E', A' la nivelul septului interventricular. Studiile publicate până în prezent arată scăderi ale velocităţii undei A, pe seama scăderii funcţiei de pompă a atriului stâng $(22,23)$.

S-a observat o scădere a excursiei sistolice a planului inelulului tricuspidian, dar și a celui mitral. Aceste modificări sunt descrise la paciente cu forme cel puţin moderate de anorexie (23). În plus, pacienții cu anorexie au prezentat valori reduse ale dimensiunilor inelului Ao și o valoare mai redusă a diametrului VCI, similar cu datele din literatură (22).

Limitările acestui studiu au fost legate de înrolarea unui număr nesemnificativ statistic de pacienți cu anorexie (patologie rară la adult, cu adresabilitate scăzută la serviciile medicale), aderența scăzută la vizitele medicale, complianța scăzută la tratamentul medicamentos și la măsurile care vizează schimbarea stilului de viață, decelarea altor boli organice în afara patologiei psihiatrice care să fi scăpat diagnosticului până în momentul examinării curente și care să determine eliminarea pacienților din studiu, interferența medicației psihiatrice în tulburările metabolice determinate de tulburările nutriţionale. Menţionăm, de asemenea, diagnosticul diferențial dificil privind aportul unei anumite patologii la o simptomatologie (ex: sindrom edematos la paciente cu hipoalbuminemie

\section{BIBLIOGRAFIE}

1. Samuels MA. The brain-heart connection. Circulation. $2007 \mathrm{Jul}$ 3;116(1):77-84.

2. Dimsdale JE. Psychological stress and cardiovascular disease. J Am Coll Cardiol. 2008;51(13):1237-1246.

3. Steptoe A, Kivimäki M. Stress and cardiovascular disease. Nat Rev Cardiol. 2012 Apr 3;9(6):360-70.

4. Marzilli E, Cerniglia L, Cimino S. A narrative review of binge eating disorder in adolescence: prevalence, impact, and psychological treatment strategies. Adolesc Health Med Ther. 2018 Jan 5;9:17-30.

5. Hail L, Le Grange D. Bulimia nervosa in adolescents: prevalence and treatment challenges. Adolesc Health Med Ther. 2018 Jan 4;9:11-16.

6. Blythin SPM, Nicholson HL, Macintyre VG, Dickson JM, Fox JRE, Taylor PJ. Experiences of shame and guilt in anorexia and bulimia nervosa: A systematic review. Psychol Psychother. 2020 Mar;93(1):134-159.

7. Udo T, Grilo CM. Prevalence and Correlates of DSM-5-Defined Eating Disorders in a Nationally Representative Sample of U.S. Adults. Biol Psychiatry. 2018 Sep 1;84(5):345-354.

8. Smink FR, van Hoeken D, Hoek HW. Epidemiology of eating disorders: incidence, prevalence and mortality rates. Curr Psychiatry Rep. 2012 Aug;14(4):406-14

9. Clausen L. Perspectives on Involuntary Treatment of Anorexia Nervosa. Front Psychiatry. 2020 Oct 21;11:533288.

10. Treasure J, Nazar BP. Interventions for the Carers of Patients With Eating Disorders. Curr Psychiatry Rep. 2016 Feb;18(2):16.

11. Henderson ZB, Fox JRE, Trayner P, Wittkowski A. Emotional development in eating disorders: A qualitative metasynthesis. Clin Psychol Psychother. 2019 Jul;26(4):440-457. severă, dar și cu insuficiență cardiacă - ponderea fiecăreia în instalarea sindromului edematos), precum şi imposibilitatea unor anumite determinări biologice necesare, utile, din motive care nu țin de personalul medical.

\section{CONCLUZII}

Modificările evidențiate în cazul pacientelor cu anorexie arată o afectare extinsă, clinică, biologică și paraclinică, ce se corelează cu indicele de masă corporală scăzut. Evidențierea modificărilor la aceste paciente, mai ales în stadii subclinice, poate duce la o netă îmbunătățire a prognosticului acestora. Este necesară o evaluare extensivă a pacienților anorexici, chiar în stadii incipiente de boală, mai ales din punct de vedere cardiovascular, pentru abordarea unei terapii nutriţionale și medicamentoase specifice. Diagnosticarea precoce a complicațiilor în cazul acestor pacienți ar duce la îmbunătăţirea speranței de viață și a calităţii vieții, precum și la scăderea costurilor serviciilor de sănătate.

Legătura dintre magnitudinea modificărilor clinice, biologice și paraclinice și indicele de masă corporală scăzut este evidentă. Sunt necesare studii ulterioare, care să stabilească gradul de reversibilitate a modificărilor după corecția totală sau parțială a deficitului nutrițional.

12. Morris J, Twaddle S. Anorexia nervosa. BMJ. 2007 Apr 28;334(7599):894-8.

13. Amianto F, Ottone L, Abbate Daga G, Fassino S. Binge-eating disorder diagnosis and treatment: a recap in front of DSM-5. BMC Psychiatry. 2015 Apr 3;15:70.

14. Westmoreland P, Krantz MJ, Mehler PS. Medical Complications of Anorexia Nervosa and Bulimia. Am J Med. 2016 Jan;129(1):30-7.

15. Brown JM, Mehler PS, Harris RH. Medical complications occurring in adolescents with anorexia nervosa. West J Med. 2000 Mar;172(3):189-93.

16. Jáuregui-Garrido B, Jáuregui-Lobera I. Sudden death in eating disorders. Vasc Health Risk Manag. 2012;8:91-8.

17. Shamim T, Golden NH, Arden M, Filiberto L, Shenker IR. Resolution of vital sign instability: an objective measure of medical stability in anorexia nervosa. J Adolesc Health. 2003 Jan;32(1):73-7.

18. Hanachi M, Pleple A, Barry C, Dicembre M, Latour E, Duquesnoy M, Melchior JC, Fayssoil A. Echocardiographic abnormalities in 124 severely malnourished adult anorexia nervosa patients: frequency and relationship with body composition and biological features. J Eat Disord. 2020 Nov 12;8(1):66.

19. de Simone G, Scalfi L, Galderisi M, Celentano A, Di Biase G, Tammaro P, Garofalo M, Mureddu GF, de Divitiis O, Contaldo F. Cardiac abnormalities in young women with anorexia nervosa. $\mathrm{Br}$ Heart J. 1994 Mar;71(3):287-92.

20. Smythe J, Colebourn C, Prisco L, Petrinic T, Leeson P. Cardiac abnormalities identified with echocardiography in anorexia nervosa: systematic review and meta-analysis. Br J Psychiatry. 2020 Feb $6: 1-10$. 
21. Galetta F, Franzoni F, Prattichizzo F, Rolla M, Santoro G, Pentimone F. Heart rate variability and left ventricular diastolic function in anorexia nervosa. J Adolesc Health. 2003 Jun;32(6):416-21.

22. Vázquez M, Olivares JL, Fleta J, Lacambra I, González M. Cardiac disorders in young women with anorexia nervosa. Rev Esp Cardiol. $2003 \mathrm{Jul} ; 56(7): 669-73$.

Conflict of interest: none declared Financial support: none declared
23. Sardar MR, Greway A, DeAngelis M, Tysko EO, Lehmann S, Wohlstetter M, Patel R. Cardiovascular Impact of Eating Disorders in Adults: A Single Center Experience and Literature Review. Heart Views. 2015 Jul-Sep;16(3):88-92. 